\title{
Myanmar in Thailand: An Empirical Study of the Relationship among the Job Characteristics Model, Job Satisfaction, Organizational Commitment, and Turnover Intention in Low-skilled Workers
}

\section{Kevalin Puangyoykeaw}

Graduate School of Economics and Management, Faculty of Economics, Tohoku University, 27-1 Kawauchi Aoba-ku Sendai, Japan 980-8576

Email: kevalin.p@gmail.com

\section{ABSTRACT}

This paper presents new empirical findings in the academically sparse area of low-skilled worker management. Despite their important presence in the labour-intensive sector, a limited amount of research and study has been done regarding low-skilled worker attitude. This empirical paper studied 400 low-skilled Myanmar immigrant workers in the Thai seafood-processing industry to find out the level of their attitude toward job satisfaction, organizational commitment, turnover intention, and job characteristic factors. Descriptive analysis, t-test, ANOVA, correlation, and regression analysis are used in this study. The results reveal a mixture of evidencesupportive to that of past literatures and a surprisingly contradictory result in the area of turnover intention. Through this new empirical finding, entrepreneurs and society gain a better understanding of low-skilled workers and understand how to manage and motivate this unique group of employees more effectively and efficiently in the future.

Keywords: job satisfaction; organizational commitment; turnover intention; job characteristic; low-skilled workers; Myanmar

JEL Classification: M540

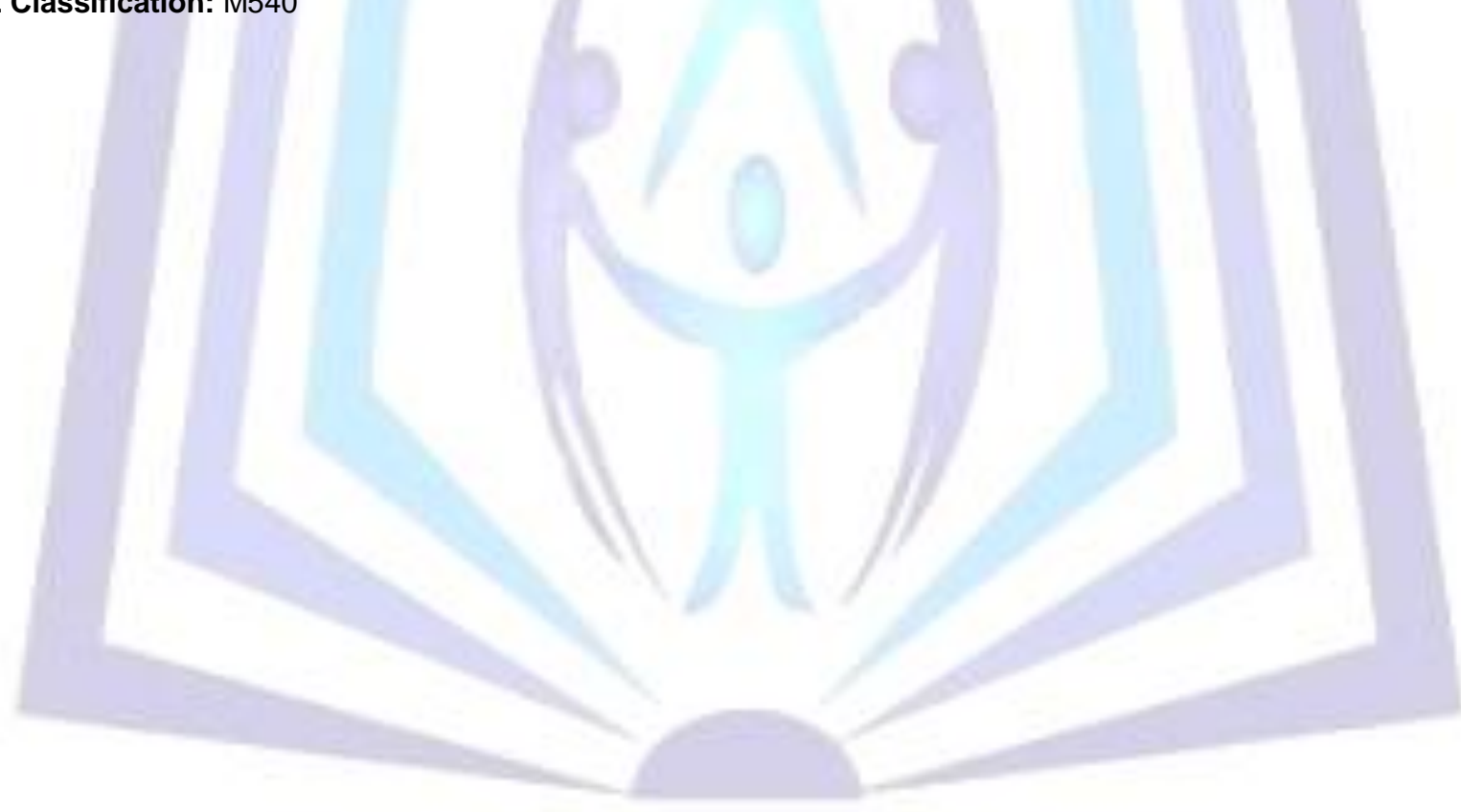

\section{Council for Innovative Research}

Peer Review Research Publishing System

\section{Journal: Journal of Social Sciences Research}

\author{
Vol. 6, No. 2
}

Jssreditor.cir@gmail.com

www.jssronline.com 


\section{INTRODUCTION}

In today's rapidly changing business environment, it is important for companies to devote their full attention and resources to nurturing and enhancing the capabilities of their committed and highly motivated human resources. It sounds logical that organizations that can utilize their human capital to the greatest extent will gain an advantage over their competitors in today's dynamic business arena. Aydogdu and Asikgil (2011) suggested one of the key success factors in business in the 2000 's is committed, productive, highly motivated, and innovative human resources. Employees who are committed have a greater tendency to exert stronger effort and good deeds to an organization. The famous work of Meyer and Allen (1997) stressed that committed employees are willing to go beyond the minimum requirements of their duties and are more likely to remain with the organization than uncommitted ones. Uncommitted individuals can lead to increasing absenteeism and actual turnover, which are costly to the firm. The turnover costs include opportunity costs, retraining costs, reselection and decreased morale of existing employees (Cho et al., 2009). It is considered to be especiallyserious for an organization tolosegood performers. Therefore, it is crucial for the firm, and the goal for every organization, to increase the satisfaction of their employees, to increase organizational commitment and to decrease turnover intention. What makes an employee leave or intend to leave become the big question for any company (Mahdi et al., 2012); thus, in-depth attention on how the organization can increase their employee commitment and retain their employees will be the focusof this paper.

Organizational commitment has been extensively researched and has emerged as a promising area of research within the study of organizational psychology (Salami, 2008; lqbal, 2010). Meyer and Allen (1990) suggested that organizational commitment reflected an employee's desire, need, and obligation to maintain membership within an organization. For the company to understand different aspects of factors that influence their employee's organizational commitment would guarantee a surplus of workforce and continuance of human resource development. Organizational commitment has proved to be an effective measurement of organizational effectiveness and helped explainvarious work-related behaviours (Mowday et al., 1982). It is used to predict important employee outcomes such as turnover, job performance, absenteeism, and tardiness (Meyer et al., 2002).

The extensive research of the study has attempted to look at the relationship among job satisfaction, organizational commitment, and turnover intention to see if there is any difference from results from other studies and to compare the differences (Yucel, 2012). In this paper, in addition to the aforementioned variable, the additional variable of job characteristics would be added. The job characteristics model (JCM; Hackman \& Oldman, 1975, 1976, 1980) proposed factors that have an impact on improving motivation, satisfaction, and performance. It is one of the most well-known theories in the field of organizational psychology. Much research has found that the JCM has an impact on job satisfaction. Therefore, in order to broaden our understanding of employee commitment level, all four variables will be studied.

Thailand, on the verge of her economic development, is now faced with a labour shortage problem especially in labourintensive industry. Thailand's continuing economic growth and her being a famous tourist destination have driven the local working generation into the service industry,makinga large gap of low-skilled labour to be filled. To overcome such a problem, labour-intensive industry hired immigrant labour from the neighbouring country, i.e. Myanmar, to fill the gap. A number of research projectscarried out based on the use of Myanmar workers in Thailand has shown little to no effect on the country's employment rate and her economic development and further stresses the importance of these immigrant workers' existence to the development of labour-intensive industry. Much research on the topic of immigrant workers has largely focused on the economic perspective of both the hosting and the home nation. Nonetheless, an empirical study paying particular attention to low-skilled employees'behaviour not only in Thailand but around the world in terms of human resource managementis sparsein the academic world. It is surprising how little is known about low-skilled workers' behaviour and attitudes.

The purpose of this study is to investigate the relationship among job characteristics, job satisfaction, organizational commitment, and turnover intention of Myanmar immigrant workers in Thailand in the seafood processing industry. It was found that very limited research had been conducted tailored to low-skilled workers, and none of the research found was conducted in the context ofthe Myanmar in Thailand. Therefore, this study aims to fill the gap others have not yet touched. This is to improve the understanding of low-skilled immigrant workers in Thailand regarding how they can be motivated and what factors make them stay within an organization. The researcher hopes that this paper can be a basis for further research in the low-skilled worker area.

\section{LITERATURE REVIEW}

\subsection{Job Characteristics Model and Employee Satisfaction}

The famous job characteristics model (JCM), introduced by Hackman \& Oldham $(1975,1980)$, is one of the most researched theories in the field of organizational psychology. The job characteristics model explores job context factors. The JCM has proven to be beneficial in understanding the current state of work as well as leavingspace to identifyroom for improvement to enhance motivation and satisfaction. A number of research findings show the strong relationship between job characteristics and job satisfaction. With the JCM, the researcher can identify a potential source of satisfaction and/or dissatisfaction stemming from the work itself and can further improve the failing. A large body of research provides evidence that the way jobs are designed impacts outcomes that are important to workers (e.g., job satisfaction) and to employers (e.g., productivity) (Panzano, Seffrin,\& Chaney-Jones, 2003). The JCM has proven to be applicable to study both the blue- and white- collar job. Hackman \& Oldham's JCM (1975) introduced five core job characteristics: skill variety, task identity, task significance, autonomy, and feedback. Most of the research has supported the validity of the JCM, although some critiques and modifications have been proposed (Vorster, Cockers, Buys, and Schaap, 2005). 
Hackman and Oldham's (1975) original terms of definition of the five core components of job characteristics model are summarized in Table 1.

Table 1: Definition of the five core components of job characteristics model

Skill Variety: Degree to which a job requires a variety of different activities in carrying out the work.

Task Identity: Degree to which the job requires completion of a whole and identifiable piece of work.

Task Degree to which the job has a substantial impact on the lives or work of other people.

Significance:

Autonomy: Degree to which the job provides substantial freedom, independence, and discretion of the employee in scheduling the work and in determining the procedures to be used in carrying it out.

Feedback: Degree in which employee obtain direct and clear information about the effectiveness of his or her performance.

Although there have been hundreds of published studies related to the JCM, this is the first known test of the JCM involving Myanmar immigrant labour in Thailand and their attitudes inlow-skilled jobs.

\subsection{Organizational Commitment and Turnover Intention}

Meyer and Allen's model of organizational commitment $(1991,1997)$ is a dominant model in the field of organizational commitment. A number of researchers conducted their empirical study based on the Meyer and Allen model. The model introduced three components of organizational commitment including a desire (affective commitment), an obligation (normative commitment), and a need (continuance commitment) (Meyer \& Allen, 1991; Liu, Norcio,\& Tu, 2009). According to Mathewman, Rose, and Hetherington (2009), commitments are the specific aspects of person's job, that is, each department, location, and group are different since each organization is complex and holdsits own agendas and goals. Organization commitment factors can be varied between the blue-collar and the white-collar labour.

Affective commitment is an individual psychological feeling of attachment and belonging to an organization. This may be the result of personal characteristics (Hartmann \& Bambacas, 2000) or the results of positive work experiences (McMahon, 2007). Just as the name suggests, affective commitment is the degree one is affectionate about,is involved with, and enjoys being a member of an organization. The studies suggested out of the threecomponents of organizational commitment, affective commitment has been most strongly linked to positive work-related behaviours (e.g., attendance, organizational citizenship behaviour) (Meyer et al., 2002; McMahon, 2007).

Continuance commitment is individual psychological decision making based on need. Continuance commitment is based on the cost associated with leaving an organization, such as reduction in pay, lossof income, lossof accrued pension, benefits, or facilities (Meyer et al., 2002; Herbiniak \& Alluto, 1972). Employees choose to remain in an organization based on continuance commitment because they need to do so (Meyer \& Allen, 1991). Unlike affective commitment, continuance commitment is a rational stage of decision-making where it reflected the perceived costs, economically and socially, associate with leaving an organization. Continuance commitment is considered to be the least form of commitment because employee only remained in an organization only out of need or lack of alternatives. Interestingly, study conducted by Van Breugel, Van Olffen, \& Ollie (2005) on the commitment of temporary employee showed temporary employee rating affective commitment higher than continuance commitment. Therefore, one's decision to stay with a particular organization is higher in term of emotion than needs.

Normative commitment is the obligation an employee feels for remaining with a particular organization (Tan \& Akhtar, 1998). The reasons for normative commitment to occur could be the feeling of indebtedness when an employer goes the extra mile in granting extra benefits to an employee such as advance payment, paying for tuition, training (Meyer \& Allen, 1991). The normative commitment has many of the same associations and consequences as affective commitment, though often to a lesser degree (McMahon, 2007). Normative commitment can be rooted in a person's own moral compass, sense of responsibility, loyalty, and sense of duty (Marsh \& Mannari, 1977). The employee stays with an organization because it is the right thing to do. Of the three components least is known about the development of normative commitment (Meyer \& Allen, 1997).

Various studies show demographic factors have an impact on the differences in employees' commitment levels(Steers \& Porter, 1983; Abdulla \& Shaw, 1999; Chughtai \& Zafar, 2006). However, some found demographic factors were not a significant predictor of employee commitment level at all (Mathieu \& Zajac, 1990; Salami, 2008). Age, education level, tenure, job position are samples of demographic variables influencing an employee's commitment level. The relationships, between demographic factors and organizational commitment have not been adequately explored and concluded.

Turnover intention is defined as one's behavioural attitude to withdrawing from the organization, whereas turnover itself is considered to be the actual separation from the organization. Turnover intention, organizational commitment, and job satisfaction are closely related to each other. When one is satisfied with an organization and has high commitment, one is unlikely to quit the firm. According to Brough and Frame (2004), job satisfaction is a strong predictor of turnover intentions and vice versa. The majority of the studies suggested that job satisfaction has a significant and positive relationship with all dimensions of organizational commitment (Bagozzi, 1980; Reichers, 1985) while show negative relationship with turnover intention (Shore \& Martin, 1989). 


\section{RESEARCH PURPOSES AND RESEARCH QUESTIONS}

The aim of this research is to investigate the relationship among job characteristics, job satisfaction, organization commitment, and turnover intention of Myanmar migrant workers in the Thaiseafood processing industry. In addition, the paper seeks to find out employees' work-related attitudes, their overall job satisfaction, the level of their commitment, and their attitude toward turnover.

In this paper, we try to answer the following questions:

- Which job characteristic variables have the largest and which have the smallest effect on job satisfaction, organization commitment, and turnover intention?

- Which type of organizational commitment in Meyer and Allen's three-component theory is highest and has most impact on turnover intention for the Myanmar immigrant workers in the Thai seafood processing industry?

- Are Myanmar workers'attitudes tojob characteristics, job satisfaction, organization commitment, and turnover intention affected by differences in demographic factors?

In light of the above-mentioned literature review, the following hypotheses were framed for the investigation of this paper:

H1: There is a positive relationship between job satisfaction and organizational commitment.

H2: There is a negative relationship between job satisfaction and turnover intention.

H3: There is a negative relationship between organizational commitment and turnover intention.

H4: There is a positive relationship between job characteristic factors and job satisfaction.

H5: There is a positive relationship between job characteristic factors and organizational commitment.

H6: There is a negative relationship between job characteristic factors and turnover intention.

The research framework demonstrating relationshipsamong the four determinants are illustrated in figure.1

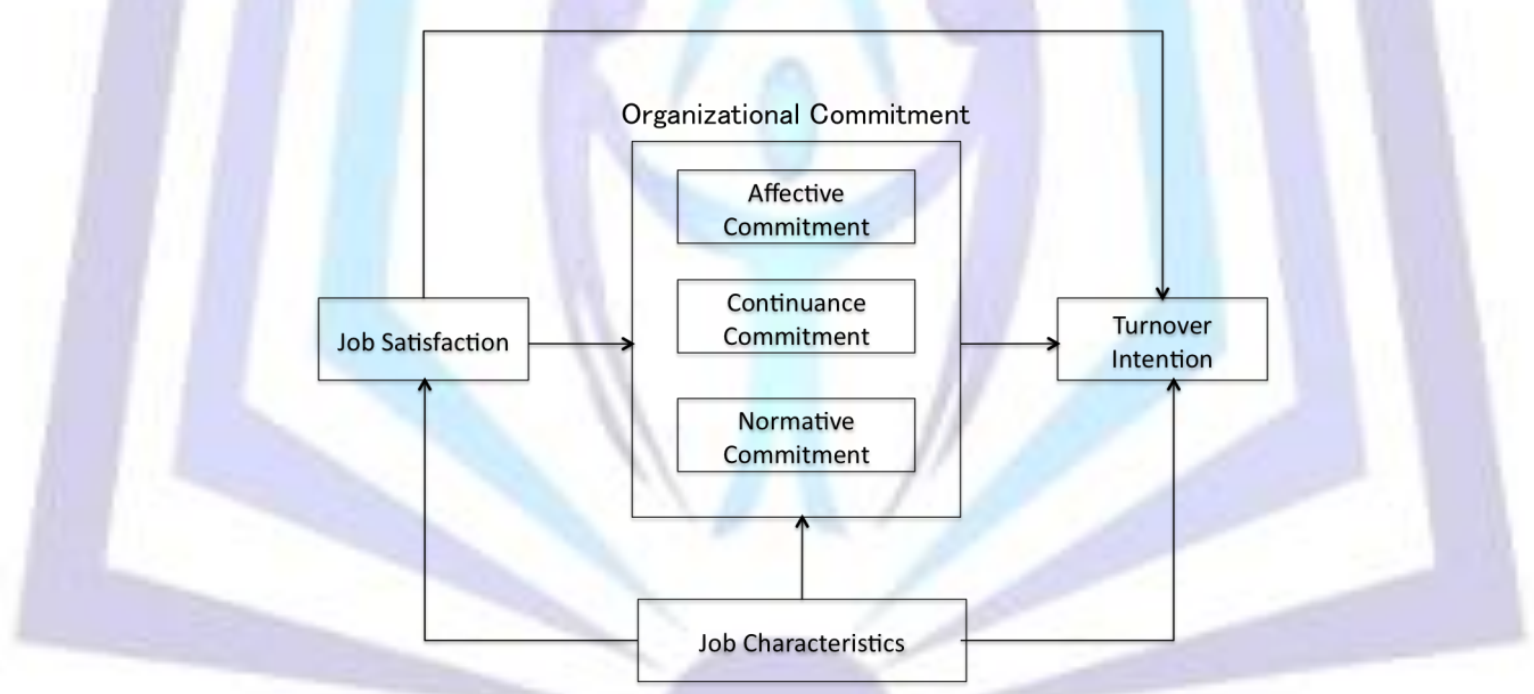

Figure 1: Research Framework

This paper aims to shed light on and improve the understanding of low-skilled Myanmar workers in Thailand. Through understanding the factors influencing organizational commitment and turnover intention, the researcher hopes that entrepreneurs and managers can create effective motivational programmes suitable for the low-skilled worker.

\section{RESEARCH METHODOLOGY}

\subsection{Sample}

The sample of this study is selected from the 13 seafood-processing factories in Samutsakorn Province, Thailand. Samutsakorn Province, or so-called Thailand Little Myanmar town, is home to Thailand's seafood industry. These 13 randomly selected factories are the factories that were granted with a 2013 immigrant hiring permit from the Thailand office workers department. The sample consists of a total of 400 questionnaires from these 13 factories using an easy random sampling technique.

\subsection{Questionnaire Instrument}


The original questionnaire was in English and was translated into Myanmar language by a translator. To prove its correctness, the questionnaire was given to another translator to back-translate into English. The questions asked in the questionnaire were carefully selected from the previous literature to ensure its validity and reliability. Taking into consideration the possibly limited literacy background of the respondents and the time constraint, the questionnaire was shortened as much as possible. The questionnaire consists of five independent sections.

Demographic Variables: including gender, age, marital status, education level, employment position, job tenure, and total length of stay in Thailand.

Measurement of Job Satisfaction: measuring respondent's general job satisfaction, the statement of "Generally speaking, I am very satisfied with my job" is asked based on the five-point Likert scale ( 1 = strongly disagree to $5=$ strongly agree). The statement developed by Dubinsky, Howell, Ingram, and Bellenger (1986) is a popular statement to measure an employee's degree of satisfaction toward their job.

Measurement of Organizational Commitment: questions were selected from Jaros' (1997) recommended list of questions. Jaros (1997) suggested a revised list of commitment scale items after analyzing Meyer and Allen's (1991; 1997) threecomponent model employee survey's validity. For affective commitment, the statement "I am a very happy member of this organization" is used. Continuance commitment is measured using the statement "It would be very hard for me to leave this organization right now, even if I wanted to" and lastly the normative commitment statement is tested by using thestatement "I feel that I owe this organization quite a bit because of what it has given me". All the questions are measured using a five-point Likert scale ( $1=$ strongly disagree to $5=$ strongly agree).

Measurement of Turnover Intention: the statement that "Nevertheless, I often think about quitting" is measured for the employee turnover intention. The questions are measured using a five-point Likert scale ( $1=$ strongly disagree to $5=$ strongly agree).

Measurement of Job Characteristics Attitude: the questions in this questionnaire were selected from section 1 of Hackman \& Oldman's (1980) Job Diagnostic Survey (JDS) to measure the five core job characteristics. The items are endorsed on a seven-point Likert scale,one item each representing the five job characteristics: skill variety, task variety, task significance, feedback, and autonomy.

\subsection{Data Analysis}

In order to answer the research questions and describe all variables, frequency distributions, measures of central tendency, and variability tests were performed. The Alpha coefficients and Pearson correlations were calculated to test the internal consistency reliability of the research questionnaire. To identify the relationship among the tested factors, the data were analyzed using statistical methods including two-tailed independent t-tests, one-way ANOVA analysis, and correlation and regression analysis.

\section{RESULTS}

The alpha reliabilities were calculated for the whole questionnaire, containing job satisfaction, organization commitment, turnover intention, and job characteristic items. The Cronbach's alpha reliability coefficients reveal good internal consistency of 0.742 .

\subsection{Respondent's Background}

Table 2: Means and Standard Deviations of Job Satisfaction, Organizational Commitment, Turnover Intention, and Job Characteristic Scale

\begin{tabular}{lccc}
\hline Scale & Mean & Std. Dev. & Skewness \\
\hline Overall Job Satisfaction & 3.32 & .845 & -.230 \\
Organizational Commitment & & & \\
- Affective Commitment & 3.31 & .818 & .021 \\
- Continuance Commitment & 3.20 & .814 & .004 \\
- Normative Commitment & 3.24 & .810 & .043 \\
Turnover Intention & 3.10 & .850 & .153
\end{tabular}

Job Characteristics

$\begin{array}{llcr}\text { - Autonomy } & 2.08 & 1.356 & 1.591 \\ \text { - Task Identity } & 2.14 & 1.196 & 1.427 \\ \text { - Skill Variety } & 2.30 & 1.308 & 1.082 \\ \text { - Task Significance } & 2.77 & 1.380 & .667\end{array}$


Descriptive analysis shows the sample consists of 247 men $(61.75 \%)$ and 153 women (38.25\%). Only $6 \%$ of the sample (24 participants) are aged less than 20 years old; $26.75 \%$ (107 participants) are between the age of 20 and 25 years old; $35.25 \%$ (141 participants) are between the ages of 26 and 30 years old; $21 \%$ (84 participants) are aged between 31 and 35 years old; and $11 \%$ (44 participants) are aged 36 years old and older. Most of the respondents are single. A total of 179 $(44.75 \%)$ are single; $111(27.75 \%)$ are married with children; $99(24.75 \%)$ are married without children; and $11(2.75 \%)$ are holding divorce status. A total of $78.25 \%$ of the sample (313 participants) are part-time workers; $21.75 \%$ of the sample (87 participants) are full-time employees. A majority of the respondents have a basic educational background. Only $7.5 \%$ (30 participants) did not attend school;20.75\% (83 participants) finished primary education; 57.25\% (229 participants) finished middle school; $12.25 \%$ (49 participants) finished high school; and 2.25\% (9 participants) have a bachelor degree. A total of 35 respondents $(8.75 \%)$ have less than a year's tenure period in the current factory they are working at; 105 respondents $(26.25 \%)$ have $1-2$ years of tenure; 148 respondents $(37 \%)$ have $2-3$ years of tenure; 70 respondents $(17.5 \%)$ have $3-5$ years of tenure; 38 respondents (9.5\%) have $5-10$ years of tenure; and 4 respondents have more than 10 years of tenure. A total of $4.25 \%$ (17 respondents) have stayed less than a year in Thailand; $16.5 \%$ (66 respondents) have stayed $1-2$ years; $33 \%$ (132 respondents) have stayed $2-3$ years; $18.5 \%$ (74 respondents) have stayed 3-5 years; $23.5 \%$ (94 respondents) have stayed $5-10$ years; and $4.25 \%$ (17 respondents) have been in Thailand for more than 10 years.

\subsection{Descriptive Analysis}

Descriptive analysis was conducted for job satisfaction, organizational commitment, turnover intention, and job characteristic items. The means, standard deviations, and the skewness for each variable are summarized in Table 2.

From an analysis, we can see that most of the answers are in their neutral stage where most of the respondents lean mostly toward neither agree nor disagree scale points for the overall job satisfaction, organizational commitment, and turnover intention. Nonetheless, affective commitment appears to be the highest commitment in the organizational commitment component while continuance commitment is the lowest for Myanmar migrant workers in Thailand.

Job characteristics, based on the seven-point scale, shows more concrete results on employees' attitudes toward their work. Most of the job characteristic variables are rated on the 2 out of 7 scale;that is, employees felt that they have fairly little autonomy in their work, that their work is a fairly small input toward the whole product, that their work required a fairly limited number of skills to finish the task, that their work is fairly insignificant, and that they got fairly little feedback from their manager or co-workers. This is not a surprising result since this reflects the normal low-skilled job characteristics where a labour-intensive job requires mostly routine and structuredtasks.

\subsection{Correlations and Regression Analysis}

To see the relationship among the four variables, a correlation matrix and multiple regressions are used to analyze the data.

A correlation matrix was calculated and is demonstrated in Table 3 . We use correlation to figure out the degree of association between the two variables. From the table, it suggests organizational commitments, all threecomponents, are positively correlated to job satisfaction and vice versa. When employees are satisfied with their job, they tend to have higher commitment toward an organization. The degree of correlation between job satisfaction and organizational commitment is highest in affective commitment, continuance commitment, and normative commitment, respectively. The Pearson correlation coefficient among the three-component organizational commitments illustrated a significant positive relationship between the three of them. Surprisingly, turnover intention shows a positive relationship with job satisfaction and with organizational commitment. Normative commitment demonstrated the highest degree of relationship among organizational commitment toward turnover intention at $r=.285, n=400, p=.00$ followed by continuance commitment at $r$ $=.246, n=400, p=.00$ and affective commitment at $r=.111, n=400, p=.026$. There was a positive correlation between job satisfaction and turnover intention at $r=.120, n=400, p=.017$. Job characteristics shows no significant relationship toward continuance commitment, normative commitment, or turnover intention. It does, however, show a correlated relationship toward job satisfaction and affective commitment. The only job characteristic that demonstrated a positive relationship between job characteristic and job satisfaction is skill variety at $r=.128, n=400, p=.010$. Skill variety also demonstrated a significant positive relationship with affective commitment at $r=.141, n=400, p=.005$. Another item in the job characteristics model that has a significant relationship with affective commitment is autonomy at $r=.108, n=400$, $p=.031$. The entire five-core job characteristics are positively correlated among each other. It supported the validity of the variable in the model. 
Table 3: Correlation Matrix for Job Satisfaction, Organizational Commitment, Turnover Intention, and Job Characteristic

\begin{tabular}{|c|c|c|c|c|c|c|c|c|c|c|}
\hline & \multicolumn{5}{|c|}{ Organizational Commitment } & \multicolumn{5}{|c|}{ Job Characteristics } \\
\hline & $\begin{array}{l}\text { Job } \\
\text { Satisfac- } \\
\text { tion }\end{array}$ & $\begin{array}{l}\text { Affective } \\
\text { Commit- } \\
\text { ment }\end{array}$ & $\begin{array}{c}\text { Continuan } \\
\text { Commit- } \\
\text { ment }\end{array}$ & $\begin{array}{c}\text { Normative } \\
\text { Commit- } \\
\text { ment }\end{array}$ & $\begin{array}{l}\text { Turnover } \\
\text { Intention }\end{array}$ & Autonomy & $\begin{array}{c}\text { Task } \\
\text { Identity }\end{array}$ & $\begin{array}{c}\text { Skill } \\
\text { Variety }\end{array}$ & $\begin{array}{l}\text { Task } \\
\text { Signifi- } \\
\text { cance }\end{array}$ & Feedback \\
\hline $\begin{array}{l}\text { Job } \\
\text { Satisfaction }\end{array}$ & 1 & & & & & & & & & \\
\hline $\begin{array}{l}\text { Affective } \\
\text { Commitment }\end{array}$ & $.411^{\prime \prime}$ & 1 & & & & & & & & \\
\hline $\begin{array}{l}\text { Continuance } \\
\text { Commitment }\end{array}$ & $.223^{* *}$ & $.276^{* *}$ & 1 & & & & & & & \\
\hline $\begin{array}{l}\text { Normative } \\
\text { Commitment }\end{array}$ & $.177^{* \pi}$ & $.176^{* *}$ & $.363^{* x}$ & 1 & & & & & & \\
\hline $\begin{array}{l}\text { Turnover } \\
\text { Intention }\end{array}$ & $.120^{*}$ & $.111^{*}$ & $.246^{* *}$ & $.285^{* *}$ & 1 & & & & & \\
\hline Autonomy & .069 & $.108^{\circ}$ & .032 & .024 & -.030 & 1 & & & & \\
\hline Task Identity & .084 & .091 & .063 & -.033 & -.036 & $.681^{* \pi}$ & 1 & & & \\
\hline Skill Variety & $.128^{\circ}$ & $.141^{*}$ & .055 & .037 & -.048 & $.698^{\prime *}$ & $.679^{* *}$ & 1 & & \\
\hline $\begin{array}{l}\text { Task } \\
\text { Significance }\end{array}$ & .000 & .059 & .052 & -.004 & .028 & $.383^{* *}$ & $.449^{\prime *}$ & $.538^{* *}$ & 1 & \\
\hline Feedback & -.026 & -.019 & .000 & -.081 & -.027 & $.467^{* \pi}$ & $.599^{* *}$ & $.599^{* \pi}$ & $.615^{x *}$ & 1 \\
\hline
\end{tabular}

In order to further understand the relationship among the four variables, causal regression analysis is calculated to reaffirm the correction of our finding.

Table 4 illustrates regression analysis on how job satisfaction (independent variable) is related to organizational commitment (dependent variable).

Table 4: Regression Analysis between Organizational Commitment and Job Satisfaction

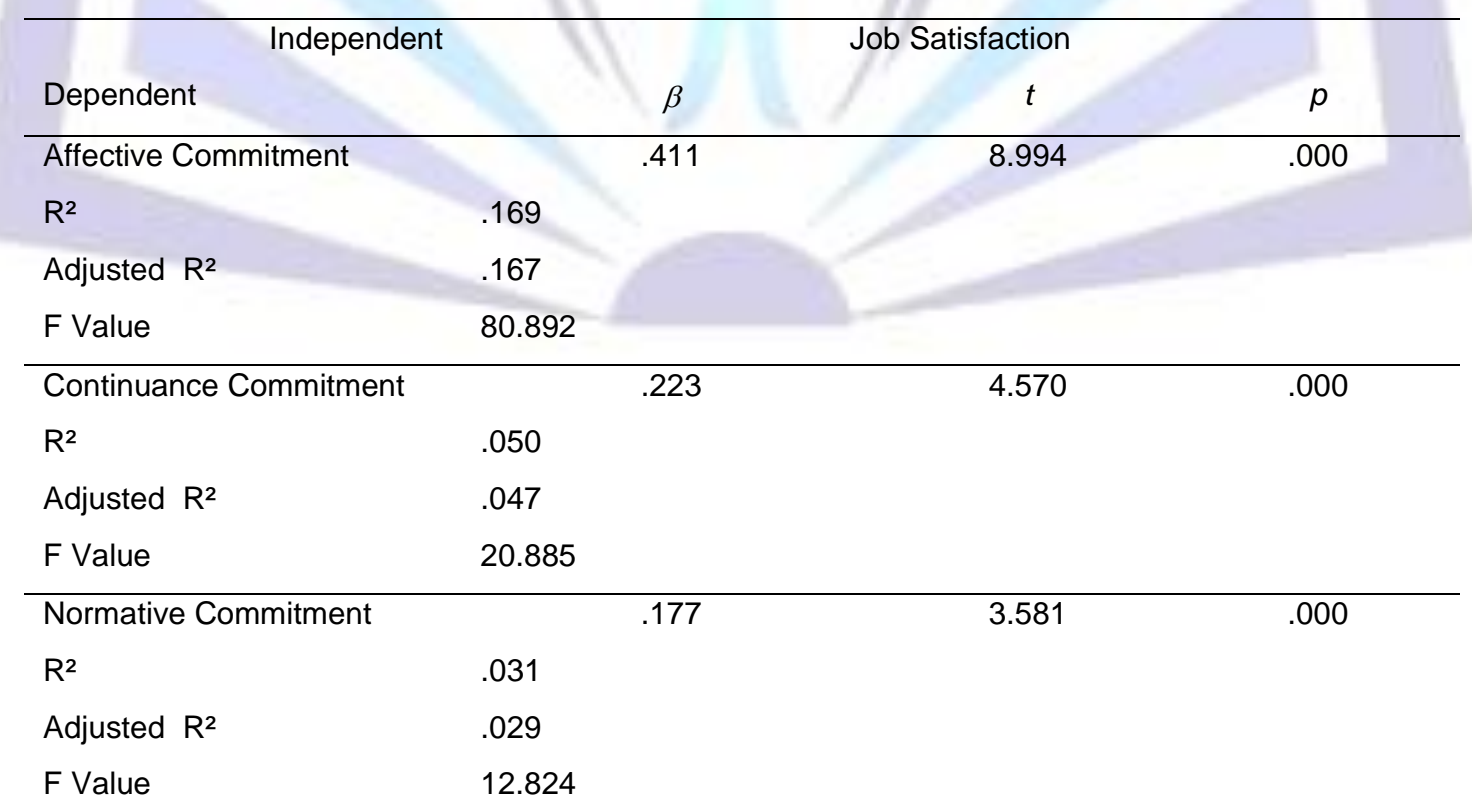

The results from Table 4 reconfirm our finding from the correlation matrix that there is a positive relationship between job satisfaction and organizational commitment. However, looking at the $\mathrm{R}^{2}$ and the adjusted $\mathrm{R}^{2}$, even though job satisfaction has a statistically significant effect on organizational commitment, the low $R^{2}$ and the adjusted $R^{2}$ suggest there are other 
variables that also have an effect on organizational commitment in addition to job satisfaction. Nonetheless, Hypothesis 1 is accepted.

Table 5 shows regression analysis on the relationship between turnover intention (dependent variable) and job satisfaction (independent variable) as well as turnover intention (dependent variable) and organizational commitment (independent variables)

Table 5: Regression Analysis among Turnover Intention, Organizational Commitment, and Job Satisfaction

\begin{tabular}{lcccc}
\hline \multicolumn{1}{c}{ Dependent } & & & Turnover Intention & \\
Independent & & $\beta$ & $t$ & \\
\hline Job Satisfaction & & .120 & 2.407 & \\
$\mathrm{R}^{2}$ & .014 & & & \\
Adjusted R ${ }^{2}$ & .012 & & & \\
F Value & 5.794 & & .575 & .566 \\
\hline Affective Commitment & & .029 & 2.998 & .003 \\
Continuance Commitment & & .157 & 4.365 & .000 \\
Normative Commitment & & .223 & & \\
$\mathrm{R}^{2}$ & .106 & & & \\
Adjusted R & .099 & & & \\
F Value & 15.576 & & & \\
\hline
\end{tabular}

As mentionedearlier, it is surprisingly interesting that both job satisfaction and organizational commitment show a positive relationship with turnover intention. This is contradictory to past literatures that suggested a negative relationship would present between job satisfaction and turnover intention, as well as organizational commitment and turnover intention;that is, when one is satisfied with their job, they are less likely to feel like quitting a company. Similarly, if an employee is committed to an organization, he or she is less likely to quit the job. This is, however, not the case for low-skilled Myanmar migrant labourers in Thailand. The low $R^{2}$ and the adjusted $R^{2}$ for relationship between job satisfaction and turnover intention only accounted for $1 \%$ of the total variance. It is doubtful and difficult to draw a concrete conclusion for this new finding. Nevertheless, hypotheses 2 and 3 are rejected;that is, in the case of Myanmar migrant workers in Thailand, job satisfaction and organizational commitment have a positive relationship to turnover intention.

Table 6 shows regression analysis between job characteristics (independent variable) and job satisfaction (dependent variable).

Table 6: Regression Analysis between Job Characteristics and Job Satisfaction

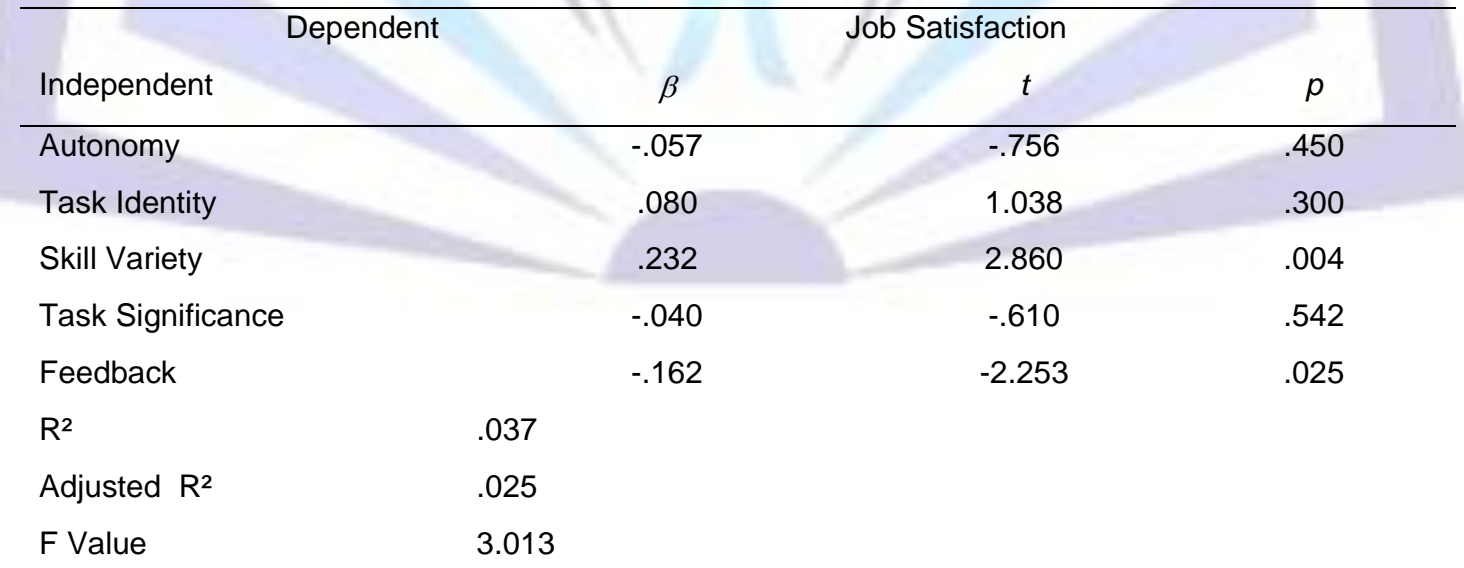

From the table, the only factor that is significant and has impact on job satisfaction is skill variety, $p=0.004$. Others have shown no significant relationship to job satisfaction. According to the majority, we conclude that job characteristics do not have a relationship with job satisfaction. Therefore, we reject hypothesis 4 .

Looking at the correlation matrix table, the only organizational commitment components which show a positive relationship to job characteristic factors is affective commitment. Job characteristics demonstrate no significant relationship to continuance commitment and normative commitment. Hypothesis 5 is rejected. 
Regression analysis was conducted between job characteristics (independent variable) and turnover intention (dependent variable). Multiple regression analysis show no significant relationship between the two $(R)=.007, p>0.01$. Hypothesis 6 is also rejected.

\subsection{Demographic Variation Analysis}

In this section, the paper aims to find out the impact of demographic variation - gender, age, education, marital status, job position, job tenure, length of stay in Thailand - on an employee's attitude toward job satisfaction, organizational commitment, turnover intention, and job characteristics. Two-tailed independent t-test and one-way ANOVA are used in this study.

For gender, there is no significant difference between the mean of male and female toward job satisfaction, organizational commitment, and turnover intention. Men and women are thinking jointly in the same direction. However, they demonstrate a difference in attitude toward job characteristics. Women show a greater level of positive attitude toward job autonomy, task identity, and skill variety when compared to men ( $p=.001, .003$ and .003, respectively).

The study also reveals a statistically significant difference in job satisfaction, turnover intention, and job characteristics attitude based on age differences. Job satisfaction level is different based on age difference, $F(6,393)=2.382, p=.028$. Post-hoc Tukey's HSD tests showed that age 36-40 years old is noticeably different from that of the other age groups. The homogeneous subsets table in Tukey's HSD test shows that the older age groups are more satisfied with their job compared to the younger group, except those aged 36-40 years old who demonstrated least satisfaction in their job. Turnover intention using ANOVA analysis based on age group reveals significant differencein the mean. However, the pairwise comparison did not show significant pairwise differences with Tukey's procedure. Age difference demonstrated different attitudes toward all job characteristic factors. The post-hoc Tukey HSD test indicated a mean score of age 20-25 is significantly different from that of the age group 36-40 in all job characteristic factors. The mean score table indicates age 20-25 has less positive attitudes toward their job compared to their older counterparts.

The difference in job position (full-time and part-time) shows noticeably different attitudes toward job satisfaction, organizational commitment, turnover intention, and job characteristics at $p<0.05$. Full-time employees are more satisfied with their job compared to part-time employees $(F=5.346, p=.021)$. Full-time employees demonstrated higher levels of affective commitment, continuance commitment, and normative commitment. Moreover, full-time employees also show a greater tendency toward turnover. For job characteristics, full-time employees present a more positive attitude toward fourcore job characteristics, namely, autonomy, task identity, skill variety, and feedback, compared to part-time employees,excepting task significance factors, where the mean between full-time and part-time employees are not significantly different.

A one-way ANOVA test was conducted to compare the relation of respondents' marital status to job satisfaction, organizational commitment, turnover intention, and job characteristics. The results show no significant difference. Marital status does not have an impact on the level of job satisfaction, organizational commitment, turnover intention, and job characteristics in the case of Myanmar migrant workers in Thailand.

There is a statistically significant difference at $p<0.05$ for job satisfaction, normative commitment, autonomy, task identity, and skill variety when looking at difference in education background $(p=.012, .004, .001, .004, .010$, respectively). Posthoc Tukey's HSD test indicated those who held a high school degree have significantly lower satisfaction when compared to those who did not attend school and hold a primary school degree.

Job tenure period, the total length of an employee's stay in the factory, has no significant impact on job satisfaction, organizational commitment, or turnover intention. Job tenure, however, has an impact on an employee's attitude toward job characteristics especially in task identity, skill variety, and task significance factors at 0.05 level of significance. Posthoc Tukey's analysis shows that those who already spend 5-10 years in the same factory have a better attitude toward the three job characteristic factors compared to those spending less time in the same factory.

The study also revealed that an employee's total length of stay in Thailand has an impact on the employee's affective commitment: $F(5,394)=2.657, p=.022$. Pairwise analysis suggested that those who spend $3-5$ years in Thailand are significantly less satisfied $\left(x^{-}=3.05, S D=.826\right)$ than those staying $5-10$ years $\left(x^{-}=3.43, S D=.783\right)$.

\section{DISCUSSION \& CONCLUSION}

The aim of this study is to reveal the relationship among job characteristics, job satisfaction, organization commitment, and turnover intention of Myanmar migrant workers in the Thai seafood processing industry, in order to improve the understanding of low-skilled workers particularly from the perspectiveof human resource management. The descriptive findings suggested Myanmar low-skilled migrant labourers felt moderately satisfied toward their jobs, hold a moderate level of attitude in organizational commitment and turnover intention. The job characteristic factors suggested plenty of room for job re-design since the job is ranked low in all fivecore job characteristics, which seems natural given the nature of the work in their low-skilled job. The finding of this study gives more empirical evidence supporting the order of importance of organizational commitment in employees. Myanmar migrant workers feel mostly committed to an organization because of the affective component, followed by the normative component, and lastly the continuance component. This result gives support to Van Breugel, Van Olffen, \& Ollie's (2005) finding that part-time employees or lowskilled workers still have high levelsof affective commitment rather than continuancecommitment and that an employee's 
decision to stay with a particular organization is largely based on emotionrather than need-based. Employers should establish emotional bonds with their employees to improve employee commitment levels.

Correlation and regression analysis proved the positive relationship between job satisfaction and organizational commitment. In the case of Myanmar migrant labourers in Thailand, job satisfaction is correlated to organizational commitment strongest in affective commitment and weakest in normative commitment.

This study further identified the relationship of job satisfaction and organizational commitment toward turnover intention. To the researcher's surprise, the results reveal contradictory results to those of past literatures. Job satisfaction and organizational commitment both have a positive relationship toward turnover intention;that is, even though an employee is satisfied with their work and is committed to the company, they still hold high intentions to leave an organization. In other words, low-skilled workers continuously look for alternative jobs. Nonetheless, it should be noted that even though the results demonstrated a positive relationship but with low $R^{2}$ and low adjusted $R^{2}$ value suggested, there are other variables that also have an effect on turnover intention that are not in the scope of this study.

The results of the study revealno significant relationship between job characteristics and job satisfaction, organizational commitment, and turnover intention. However, a small correlation exists in the skill variety job characteristic factor toward job satisfaction and affective commitment; that is, to a certain extent, giving the employee greater variety of workso that they can extend their skills is likely to improve their job satisfaction as well as their affective commitment level. Moreover, autonomy also shows a small correlation with affective commitment. With this finding, companies should consider job rotation for low-skilled employees to expose them to a larger variety of tasks in order to increase their satisfaction as well as commitment.

Demographics variation analysis validated an assumption that differences in a respondent's background would result in a different impact on job satisfaction, organizational commitment, turnover intention, and job characteristics attitude. There are significant different attitudes when considering differences in the respondent's gender, age, employee position, education level, job tenure, and total length of stay in Thailand. Marital status, however, in the content of Myanmar in Thailand, does not show significant difference toward job satisfaction, organizational commitment, turnover intention, and job characteristic. For Gender, men and women do not feel differently toward job satisfaction, organizational commitment, and turnover intention. However, women demonstrated more positive attitudes toward job characteristic factors than men;that is, women feel their job is more valuable than men think. For differences in Age, an empirical finding shows age has an impact on job satisfaction, turnover intention, and job characteristic factors. The analysis supported the literature that age is one of the main factors affecting job satisfaction and that the older workers are more likely to satisfied with their work than their younger counterparts. This also reflected in job characteristics attitude. Age group 20-25 is has significantly less positive attitudes toward their current job when compared to the older generation. Age plays an important role in influencing an employee's attitude. This may be due to how employees adapt their expectation after gaining more life experiences. The results of this study also supported those demonstrating how Employment Position largely affects employee motivational levels. A full-time employee shows greater motivation in job satisfaction, organizational commitment, turnover intention, and job characteristics attitude when compared to a part-time employee. Giving full-time positions to good performers will increase their satisfaction as well as their morale toward organization. Differences in Education level will result in different attitudes toward job satisfaction, organizational commitment, and job characteristics. Those with academic degrees demonstrated less satisfaction compared to those without a degree. Job tenure only shows significant difference toward job characteristic factors. Those who spend greater amounts of time in the same factory show a greater level in attitude toward task identity, skill variety and task significance when compared to the less experienced workers.

Therefore, in an empirical study of Myanmar migrant workers in Thailand, older, more experienced, full-time, and less literate individuals will show greater satisfaction and higher organizational commitment when compared to younger, less experience, part-time, and high educated individuals.

\section{FUTURE DIRECTION \& LIMITATIONS}

The findings of this empirical study highlight some interesting results. However, for future research in a similar topic and direction, the following point should be considered to improve future research findings.

The sample size of this study is limited to the 400 questionnaires randomly selected from 13 seafoodprocessing factories in Samutsakorn province. In order to gain better understanding of Myanmar migrant workers in Thailand a larger sample size, as well as samples studied in another industry, could reveal more concrete results to back up the findings.

The questionnaire used in the current study is short and precise. Nonetheless, for further study an in-depth questionnaire could help to improve the exploration of the relationship amongjob satisfaction, organizational commitment, turnover intention, and job characteristicsfor low-skilled workers. Larger question items per variable would be a positive addition, in order to improve the reliability of the questionnaires. Job characteristics' critical psychological states are not included in this questionnaire. For future research, including the critical psychological states could help better understand low-skilled workers' attitudes toward their job. Lastly, this research found contradicting results regarding turnover intention in lowskilled workers. A detailed study of this issue would be interesting and would add a new finding in the area of low-skilled worker studies.

\section{REFERENCES}




\section{ISSN 2321-1091}

Abdulla, M.H.A.,\& Shaw, J.D. 1999. Personal Factors and organizational commitment: Main and interactive effects in the United Arab Emirates. Journal of Managerial Issues, 11, 77-93.

Allen, N. J., \& Meyer, J. P. 1990. The measurement and antecedents of affective, continuance and normative commitment to the organization. Journal of Occupational Psychology, 63, 1-18.

Aydogdu.S., \& Asikgil, B. 2011. An empirical study of the relationship among job satisfaction, organizational commitment and turnover intention. International Review of Management and Marketing, 1(3), 43-53.

Bagossi, R.P. 1980.Causal Models in Marketing. New York:John Wiley \& Sons

Brough, P.,\& Frame, R. 2004. Predicting police job satisfaction, work well-being and turnoverintentions: The role of social support and police organisational variables. Journal of Psychology, 33, 8-18.

Chughtai, A., \& Zafar, S. 2006. Antecedents and consequences of organizational commitment among pakistani university teachers. Applied H.R.M. Research, 11, 39-64.

Cho, S., Johanson, M.M., Guchait, P. 2009. Employees intent to leave: a comparison of determinants of intent to leave versus intent to stay. International Journal of Hospitality Management, 28(3), 374-381.

Dawal, S.Z., Taha, Z., Ismail, Z. 2009. Effect of job organization on job satisfaction among shop floor employees in automotive industries in Malaysia. International Journal of Industrial Ergonomics 39, 1-6

Dore, T.L. 2004. The relationship between job characteristics, job satisfaction, and turnover intention among software developers. Dissertation for Doctor of Business Administration. Graduate school of Argosy University, Orange County.

Dubinsky, A. J., Howell, R. D., Ingram, T. N., \& Bellenger, D. 1986. Salesforce socialization. Journal of Marketing, 50, 192-207.

Hackman, J.,\& Oldham,G. 1975. Development of the job diagnostic survey. Journal of Applied Psychology, 60(2), 159170.

Hackman, J.R. \& Oldham, G.R. 1976. Motivation through the design of work: Test of a theory. Organizational Behaviour of Human Performance, 16 (2), 250-279.

Hackman, J.R. \& Oldham, G.R. 1980. Work redesign. Reading, MA: Addison- Wesley.

Hartmann, L. C., \& Bambacas, M. 2000. Organizational commitment: A multimethod scale analysis and test of effects. International Journal of Organizational Analysis, 8(1), 89-108.

Herbiniak, L. G., \& Alluto, J. A. 1972. Personal and role related factors in the development of organizational commitment. Administrative Science Quarterly,17(4), 555-573.

lqbal, A. 2010. An empirical assessment of demographic factors, organizational ranks and organizational commitment. International Journal of Business and Management, 5(3).

Jaros, S. 1997. An assessment of Meyer and Allen's (1991) three-component model of organizational commitment and turnover intentions. Journal of Vocational Behavior, 51, 319-337.

Liu, S.W., Norcio, R., \&Tu, J.T. 2009. The differencesin job characteristics, job satisfaction, and organizational commitment of Taiwanese expatriates working in mainland china. International Journal of Business and Management, 4(11).

McMahon, B. 2007. Organizational commitment, relationship commitment and their association with attachement style and locus of control.Partial fulfillment of Master of Science Degree in Psychology. Gerogia Institute of Technology.

Mahdi, A.F., Mohd Zin, M.Z., Mohd Nor, M.R., Skat, A.A., Abang Naim, A.S. 2012. The relationship between job satisfaction and turnover intention. American Journal of Applied Sciences, 9(9), 1518-1526.

Marsh, R. M., \& Mannari, H. 1977. Organizational commitment and turnover: A prediction study. Administrative Science Quarterly, 22(1), 57-75.

Mathewman, L., Rose, A., \& Hetherington, A. 2009. Work Psychology. New York: Oxford University Press.

Mathieu, J., \& Zajac, D. 1990. A review and meta-analysis of the antecedents, correlates, and consequences of organizational commitment. Psychological Bulletin, 108(2), 171-194.

Meyer, J.P, \&Allen, N. J. 1991. A three-component conceptualization of organizational commitment. Human Resource Management Review,1(1), 61-89.

Meyer, J.P, \& Allen, N. J. 1997. Commitment in the workplace. Thousand Oaks, CA: SAGE Publications. 


\section{ISSN 2321-1091}

Meyer, J.P, Stanley, D.J., Herscovitch, L., and Topolnytsky, L. 2002.Affective, continuance and normative commitment to the organization: a meta-analysis of antecedents, correlates, and consequences. Journal of Vocational Behavior, 61, 2052.

Mowday, R. T., Porter, L. W., \& Steers, R. M. 1982. Employee-organizational linkages: The psychology of commitment, absenteeism, and turnover. New York: Academic Press.

Panzano, P.C., Seffrin, B.A., Jones, S.C.H. 2002-2003. Examining the value of the job characteristics model for improving the experience of work and work-related outcomes for adults with severe and persistent mental illness.In: New Research in Mental Health,16. Decision Support Services, Inc.

Reichers, Arnon E. 1985. A Review and Reconceptualization of Organizational Commitment. Academy of Management Review, 10(3), 465-476.

Salami, S. O. 2008. Demographic and psychological factors predicting organizational commitment among industrial workers. Anthropologist, 10, 31-38.

Shore, L. M., \& Martin, H. J. 1989. Job satisfaction and organizational commitment inrelation to work performance and turnover intentions. Human Relations, 42(7), 625-638.

Steers, R.M. and L.W. Porter. 1983. Motivation and Work Behavior. (4th ed.). New York: McGraw-Hill.

Tan, D.S.K, \& Akhtar, S. 1998. Organizational commitment and experience burnout: An exploratory study from a Chinese cultural perspective. International Journal of Organizational Analysis, 6(4), 310-333.

Van Breugel, G., Van Olffen, W., \& Ollie, R. 2005. Temporary liaisons: The commitment of ëtempsí toward their agencies. Journal of Management Studies, 42(3), 539-566.

Vorster, M., Olckers, C., Buys, M.A., Schaap, P. 2005. The construct equivalence of the job diagnostic survey for diverse South African cultural groups. Journal of Industrial Psychology, 31(1), 31-37.

Yucel, I. 2012. Examining the relationship among job satisfaction, organizational commitment, and turnover intention: an empirical study. International Journal of Business and Management, 7(20). 